\title{
PERANCANGAN E-COMPLAINT UNTUK MENINGKATKAN MUTU PELAYANAN PADA DINAS KESEHATAN LUBUKLINGGAU MENGGUNAKAN METODE SERVQUAL
}

\author{
Rahman Kurniawan $^{1)}$, Alfiarini ${ }^{2)}$ \\ Sistem Informasi, STMIK Bina Nusantara Jaya Lubuklinggau \\ Jl. Yos Sudarso No.97 A Kel. Jawa Kanan, Kota Lubuklinggau, Sumatera Selatan \\ kurniawanrahman39@gmail.com ${ }^{1)}$, alfiarini3@ gmail.com ${ }^{2)}$
}

\begin{abstract}
Public services of various new concepts and techniques in the service satisfaction survey system have been widely developed to replace the survey method by manual only relying on socialization in which the survey was conducted at a predetermined time and place. One survey method that is developing in the present is e-complaint using the servqual method. E-complaint can help employees conduct surveys and servqual methods help in calculations, this can maximize the survey time that can be done at any time. The research methodology used in compiling this thesis is a library study while the system development stage uses a prototype method. Designing applications that will be built using structured methods using UML tools. The e-complaint application that will be built using PHP and $M Y S Q L$ programming languages as a database. The results of this study are that an e-complaint application program will be built to improve service quality at the Lubuklinggau City Health Office. The system testing used is the Black-Box method. With the system to be built e-complaint can help conduct complaints filling surveys so that the respondent does not need to wait when socializing at the time that has been set, and can facilitate employees in collecting data to calculate the value of complaints in an effort to improve service quality.
\end{abstract}

Keywords : E-Complaint, Public Service, Dinas Kesehatan

\begin{abstract}
Abstrak
Pelayanan publik berbagai konsep dan teknik baru dalam sistem survei kepuasan pelayanan telah banyak dikembangkan untuk mengantikan metode survei dengan cara manual hanya mengandalkan sosialisasi yang dimana survei dilakukan pada waktu dan tempat yang telah ditentukan. Salah satu metode survei yang sedang berkembang di masa sekarang yaitu e-complaint menggunakan metode servqual. E-complaint dapat membantu para pegawai melakukan survei dan metode servqual membantu dalam perhitungan, hal ini dapat memaksimalkan waktu survei yang dapat dilakukan kapan pun. Metodelogi penelitian yang digunakan dalam menyusun skripsi ini adalah studi pustak sedangkan tahap pengembangan sistem menggunakana metode prototype. Merancang aplikasi yang akan dibangun digunakan metode terstruktur dengan menggunakan tools UML. Aplikasi e-complaint yang akan dibangun menggunakan bahasa pemrogram PHP dan MySQL sebagai database. Hasil penelitian ini adalah akan dibangun sebuah program aplikasi ecomplaint untuk meningkatkan mutu pelayana pada Dinas Kesehatan Kota Lubuklinggau. Pengujian sistem yang digunakan adalah metode Black-Box. Dengan sistem yang akan dibangun e-complaint dapat membantu melakukan survei pengisian komplain sehinggan responden tidak perlu menunggu ketika sosialisasi pada waktu yang telah di tetapkan, dan dapat mempermudah pegawai dalam pengumpulan data untuk menghitung nilai hasil komplain dalam upaya meningkatkan mutu pelayanan.
\end{abstract}

Kata kunci: e-complaint, servqual, pelayanan publik, Dinas Kesehatan

\section{Pendahuluan}

LV.Sahfitri (2014) menyatakan komplain merupakan bentuk ekspresi negatif yang dihasilkan dari ketidaksesuaian antara kenyataan dan keinginan seseorang.[1] Salah satu indikator untuk pengukuran penilaian mutu pelayanan dari sebuah perkantoran yaitu dari komplain pengguna. Kepuasan para pengguna merupakan suatu keadaan dimana sebagian besar keinginan, harapan dan kebutuhan yang dipenuhi. Mutu pelayanan dapat terhubung langsung dengan kesetiaan pengguna dan kebutuhan utama dari loyalitas pengguna yang secara konsisten mampu memuaskan penggunanya akan mendapatkan citra positif tinggi. 
Agar dapat mengetahui layanan yang diberikan telah memenuhi keinginan dan harapan yang memuaskan kebutuhan pengguna, maka harus dilakukan pengukuran dari hasil keluhan pengguna. Pengguna merupakan langkah penting dalam upaya meningkatkan layanan yang lebih baik.

Berdasarkan hasil dari observasi penyampaian keluhan masyarakat yaitu dengan mengisi selembaran. salah satu keluhan yang disampaikan masyarakat adalah lambatnya proses pengurusan sarana dan prasaranan yang berkaitan dengan proses pelayanan. Selain itu belum adanya metode penilaian yang digunakan sehingga perlu perhatian dan perbaikan untuk meningkatkan mutu dan kualitas pelayanan pada Dinas Kesehatan. Dari permasalahan yang ada dirasa perlu suatu sistem terkomputerisasi yang disebut dengan sistem E-Complaint untuk mempermudah menyampaikan keluhan dan menganalisis hasil keluhan dengan menggunakan metode servqual agar dapat mengetahui pelayanan yang perlu di perbaiki.

\section{Tinjauan Pustaka}

\section{1) Definisi Perancangan}

Menurut Susanto (2015)perancangan merupakan spesifikasi umum dan rinci dari pemecahan masalah berbasis komputer yang telah dipilih selama tahap analisis. Tahap perancangan dalam pengembangan sistem adalah tahap paling penting, dimana pada tahap perancangan akan diadakan identifikasi masalahmasalah apa yang akan digunakan sebagai bahan rancangan, sehingga dapat menghasilkan sistem informasi yang baik.[2]

\section{2) Definisi Sistem}

Menurut Stoa (2012) sistem adalah gabungan dari keseluruhan langit dan bumi yang saling bekerja sama yang membentuk suatu keseluruhan dan apabila salah satu unsur tersebut hilang atau tidak berfungsi, maka gabungan keseluruhan tersebut tidak dapat lagi kita sebut suatu sistem.[3]

\section{3) DefinisiE-Complaint}

Menurut Tjiptono (2016) complaint merupakan secara sederhana, complaint bisa diartikan sebagai ungkapan ketidakpuasan atau kekecewaan.[4] Sedangkan menurut Leboeuf (2016)complaint merupakan suatu peluang untuk memperkuat loyalitas pengguna.[4]

4) Definisi Pelayanan
Samsara (2013) menyatakan pelayanan merupakan kegiatan demi menguntungkan dalam suatu kesatuan ditawarkan untuk kepuasan walaupun hasilnya tidak terikat dengan suatu produk secara fisik.[5]

5) Definisi Pelayanan Publik

Menurut UU No.25 Tahun 2009 (2014) Pelayanan publik merupakan kegiatan dalam rangka pemenuhan kebutuhan pelayanan pengguna atau masyarakat sesuai dengan peraturan perundang-undangan bagi setiap warga negara dan penduduk atas barang, jasa dan pelayanan administratif yang disediakan oleh penyelenggara pelayanan publik.

Komponen standarpelayanan public menurut Pasal 21 Undang-Undang No 25 Tahun 2009 sekurangkurangnya meliputi:

1) Dasar hukum, yaitu peraturan perundangundangan yang menjadi dasar penyelenggaraan pelayanan.

2) Persyaratan, yaitu syarat yang harus dipenuhi dalam pengurusan suatu jenis pelayanan, baik persyaratan teknis maupun administratif.

3) Sistem, mekanisme, dan prosedur, yaitu tata cara pelayanan yang dibakukan bagi pemberi dan penerima pelayanan, termasuk pengaduan.

4) Jangka waktu penyelesaian, yaitu jangka waktu yang diperlukan untuk menyelesaikan seluruh proses pelayanan dari setiap jenis pelayanan.

5) Biaya/tarif, yaitu ongkos yang dikenakan kepada penerima layanan dalam mengurus dan/atau memperoleh pelayanan dari penyelenggara yang besarnya ditetapkan berdasarkan kesepakatan antara penyelenggara dan masyarakat.

6) Produk pelayanan, yaitu hasil pelayanan yang diberikan dan diterima sesuai dengan ketentuan yang telah ditetapkan.

7) Sarana, prasarana, dan/atau fasilitas, yaitu peralatan dan fasilitas yang diperlukan dalam penyelenggaraan pelayanan, termasuk peralatan dan fasilitas pelayanan bagi kelompok rentan.

8) Kompetensi pelaksana, yaitu kemampuan yang harus dimiliki oleh pelaksana meliputi pengetahuan, keahlian, keterampilan, dan pengalaman.

9) Pengawasan internal, yaitu Pengendalian yang dilakukan oleh pimpinan satuan kerja atau atasan langsung pelaksana.

10) Penanganan pengaduan, saran, dan masukan, yaitu Tata cara pelaksanaan penanganan pengaduan dan tindak lanjut.

11) Jumlah pelaksana, yaitu tersedianya pelaksana sesuai dengan beban kerja.

12) Jaminan pelayanan yang memberikan kepastian pelayanan dilaksanakan sesuai dengan standard pelayanan. 
13) Jaminan keamanan dan keselamatan pelayanan dalam bentuk komitmen

14) untuk memberikan rasa aman, bebas dari bahaya, dan risiko keraguraguan, yaitu Kepastian memberikan rasa aman dan bebas dari bahaya, risiko, dan keragu-raguan.

15) Evaluasi kinerja pelaksana yaitu penilaian untuk mengetahui seberapa jauh pelaksanaan kegiatan sesuai dengan standar pelayanan.

Standar pelayanan publik (selanjutnya disebut SPP) merupakan standar pelayanan yang wajib disediakan oleh pemerintah kepada masyarakat. Adanya SPP akan menjamin pelayanan minimal yang berhak diperoleh warga masyarakat dari pemerintah. Dengan kata lain, SPP merupakan tolok ukur untuk mengukur kinerja penyelenggaraan kewenangan wajib yang berkaitan dengan pelayanan dasar kepada masyarakat seperti: kesehatan, pendidikan, air minum, perumahan dan lainlain. Di samping SPP untuk kewenangan wajib, daerah dapat mengembangkan dan menerapkan standar kinerja untuk kewenangan daerah yang lain.[6]

\section{6) Definisi Metode Servqual}

Menurut Brysland (2014) metode servqual adalah metode yang dipandang memenuhi syarat validitas secara statistik. Kualitas pelayanan perlu diukur dengan tiga alasan, yaitu :

1) Hasil digunakan untuk sebagai perbandingan antara sesudah dan sebelum terjadi dari perubahan pada suatu organisasi.

2) Untuk mengidentifikasi permasalahan yang terkait dengan kualitas

3) Dipergunakan untuk menetapkan standar kualitas pelayanan.

Dalam [7], bahwa skor servqual untuk setiap pertanyaan masing pengguna dapat dihitung dengan rumus sebagai berikut :

Skor Servqual = Skor Persepsi - Skor Harapan

Data diperoleh melalui instrumen servqual dapat dipergunakan menghitung skor gap kualitas pelayanan pada berbagai level secara rinci, seperti berikut :

1) Item-by-item analysis, misal P1-H1, P2-H2, P3P3, dan seterusnya.

2) Dimension-by-dimension analysis, misal, ( $\mathrm{P} 1+$ $\mathrm{P} 2+\mathrm{P} 3+\mathrm{P} 4) / 4-(\mathrm{H} 1+\mathrm{H} 2+\mathrm{H} 3+\mathrm{H} 4) / 4$ yang dimana P1 sampai P4 dan H1 sampai H4 mencerminkan 4 pertanyaan persepsi dan harapan yang berkaitan dengan dimensi.

Ukuran tunggal perhitungan kualitas layanan atau gap Servqual, yaitu $(\mathrm{P} 1+\mathrm{P} 2+\mathrm{P} 3+\mathrm{P} 4+\ldots+\mathrm{P} 22) / 22$ $(\mathrm{H} 1+\mathrm{H} 2+\mathrm{H} 3+\mathrm{H} 4+\ldots+\mathrm{H} 22) / 22 .[7]$

\section{Metodologi Penelitian}

\subsection{Metode Perancangan Sistem}

1) Analisis Sistem

Dalam tahap ini dilakukan analisa terhadap kebutuhan pengguna aplikasi e-complaint untuk meningkatkan mutu pelayanan pada Dinas Kesehatan Lubuklinggau. Kebutuhan pengguna tersebut yaitu pengujung, admin dan pimpinan. Penulis menjelaskan tentang analisis prosedur kerja, analisis pemecahan masalah, kebutuhan fungsional dan kebutuhan non fungsional. Dimana kebutuhan fungsional pada perancangan e-complaint untuk meningkatkan mutu pelayanan pada Dinas Kesehatan Lubuklinggau menggunakan metode servqual terdiri dari pendataan pengunjung, pendataan komplain, pendataan dimensi dan pendataan user. Sedangkan kebutuhan non fungsional membahas tentang spesifikasi yang dibutuhkan olah sistem serta pendukung perangkat lunaknya.

\section{2) Analisis Prosedur Kerja}

Pada suatu perusahaan dibutuhkan informasi untuk membangun kinerja yang ada di perusahan tersebut. Seperti halnya pada Dinas kesehatan Kota Lubuklinggau. Saat ini prosedur kerja yang dilakukan adalah proses pendataan kepuasan atau rasa ketidakpuasan masyarakan dengan cara pengisian komplain yang dimana komplain yang dilakukan masih berupa lembaran. Setelah itu dilakukan rekaputulasi data bulanan di laporkan kepada pimpinan yang akan di tindak lanjutkan dari hasil komplain. Maka dapat di ketahui yang perlu di perbaiki dan sanksi terhadapat pegawai jika ada yang melakukan kesalahan. Dengan cara demikian keterbatasannya dalam melakukan komplain karena masyarakat harus datang langsung ke instansi untuk melakukan komplain dan petugas harus merekap komplain satu persatu untuk dianalisis.

\section{3) Analisis Pemecahan Masalah}

Dari analisis prosedur kerja pada Dinas Kesehatan Kota Lubuklinggau pemecahan masalah yaitu sebelum masyarakat melakukan komplain harus malakukan registrasi terlebuh dahulu. Setelah melakukan registrasi masyarakat baru dapat melakukan komplain yang dimana komplain dapat dilakukan sebulan sekali. Data komplain akan tersimpan ke dalam database maka admin akan memeriksa komplain apakah melanggar kebijakan. Jika melanggar admin akan memberikan informasi bahwa komplain tidak dapat di proses, jika tidak melanggar komplain akan diteruskan yang akan di proses oleh pimpinan dan masyarakan mendapatkan informasi balasan komplain telah di tindak lanjut. Dari 
data komplain aplikasi melakukan analisis menggunakan metode servqual yang terbagi menjadi 5 dimensi berdasarkan nilai dari responden dan nilai harapan dari instansi yang dimana hasil rata-ratanya menjadi hasil akhir dari dimensi yang memiliki nilai terendah perlu dilakukan perbaikan. Maka setiap bulannya pimpinan akan mendapatkan laporan dari rekapitulasi hasil komplain.

\section{1) Use Case admin}

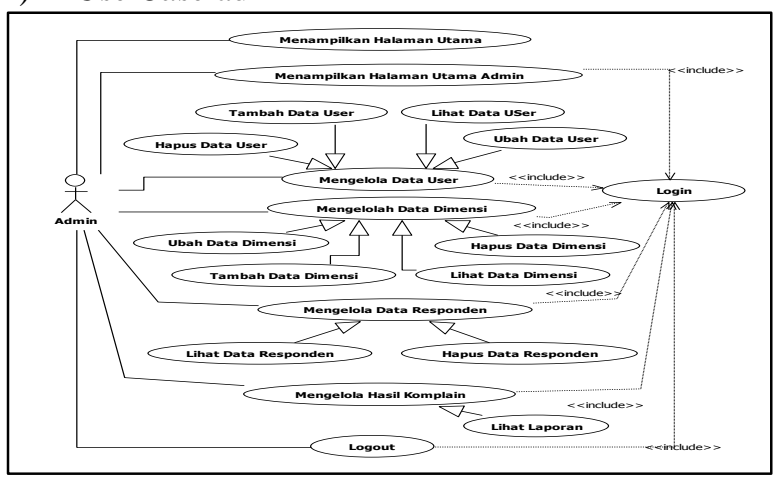

Gambar 1. Halaman Use Case admin

Gambar diatas merupakan use case diagram admin. Pada saat admin akan melakukan pengolahan data seperti data user, data dimensi, data responden, data hasil komplain admin harus malakukan login dahulu. Admin juga dapat mengubah data bila ada perubahan data.

\section{2) Activity Diagram Admin}

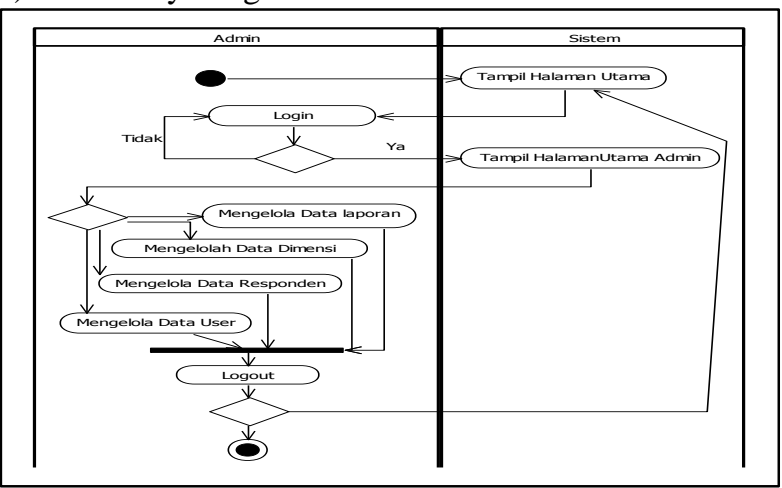

Gambar 2. Halaman Activity Diagram Admin

3) Sequence Diagram Tambah Data Komplain

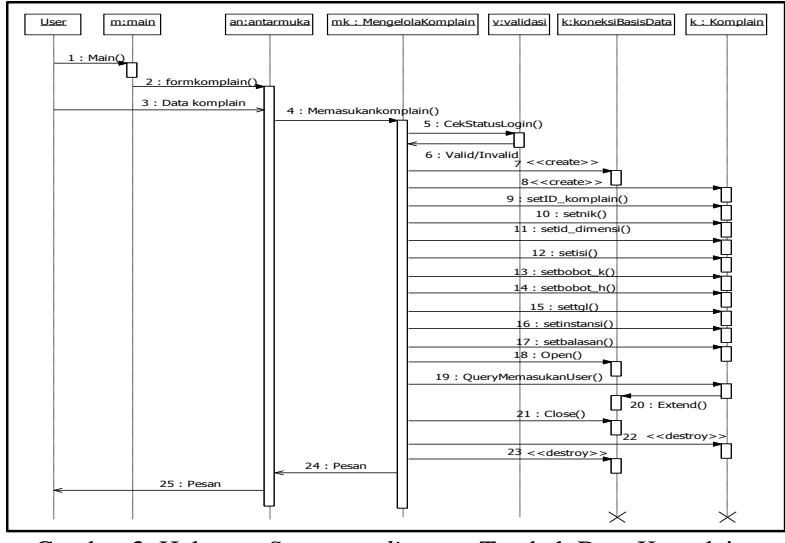

Gambar 3. Halaman Sequence diagram Tambah Data Komplain

1. Class Diagram

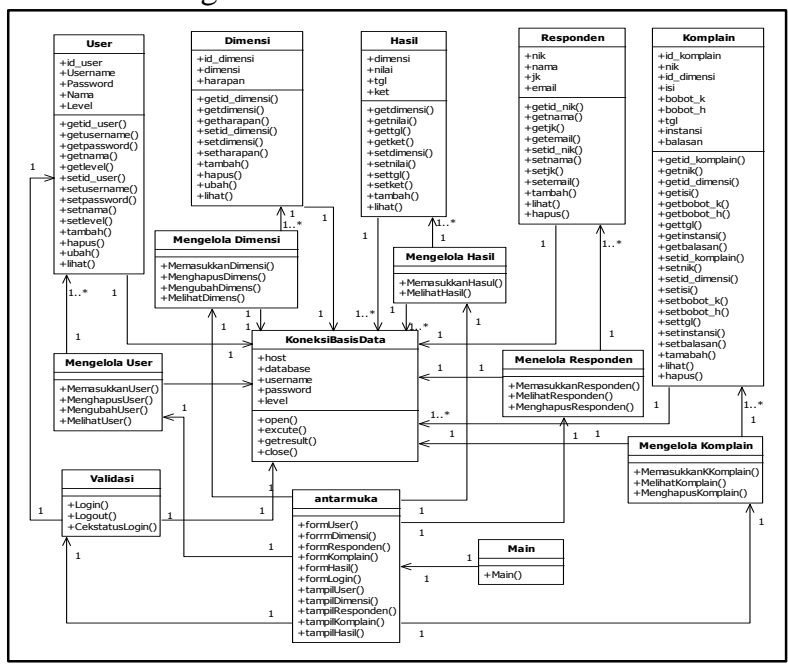

Gambar 4. Halaman Class Diagram

\section{Hasil Dan Pembahasan}

\subsection{Hasil Implementasi}

1) Halaman Login

Login user digunakan untuk masuk kehalaman akses sesuai dengan level yang telah ditentukan 


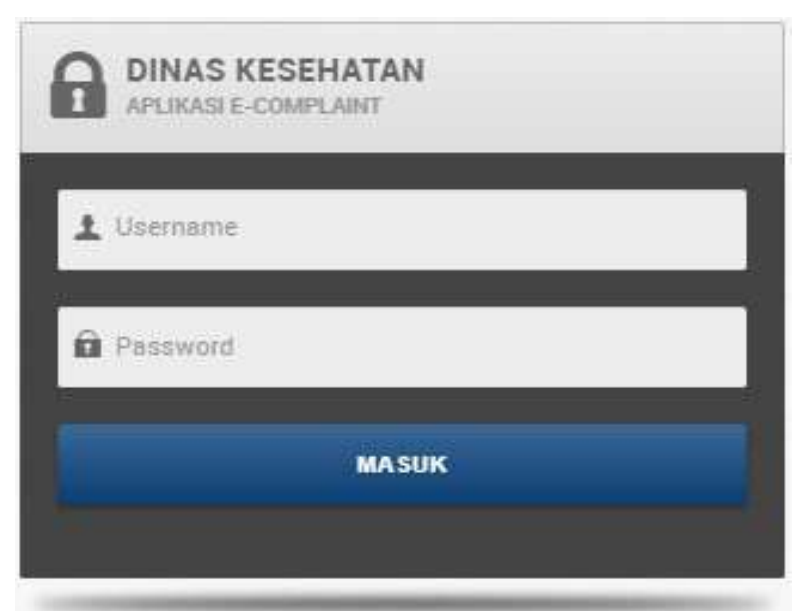

Gambar 5. Halaman Login

\section{2) Halaman Utama Sistem}

Halaman Utama merupakan halaman yang akan muncul pertama kali ketika usermasuk ke sistemEComplaint.

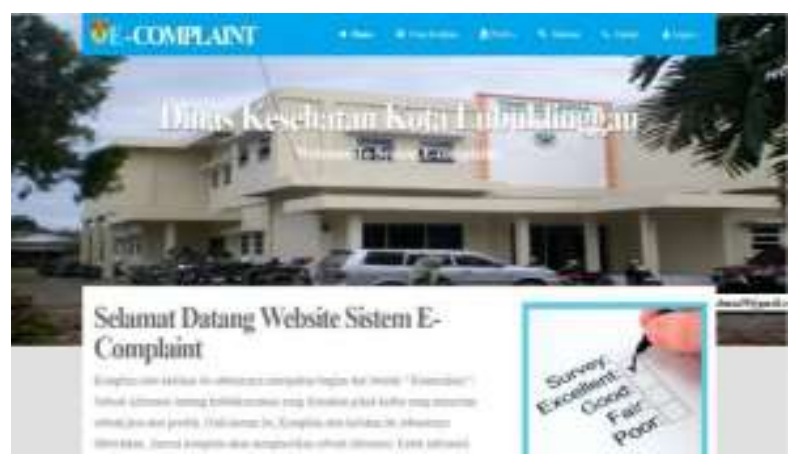

Gambar 6. Halaman Utama Sistem

\section{3) Halaman Registrasi}

Pertama responden akan melakukan registrasi berfungsi untuk responden mengisi data diri sebelum melakukan komplain.

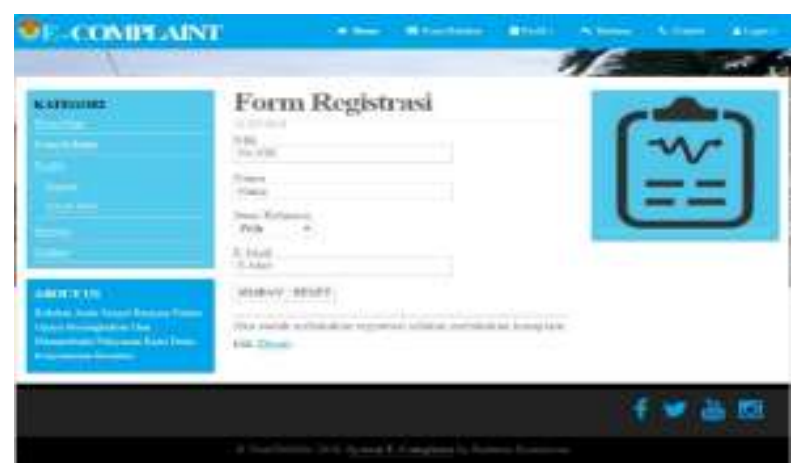

Gambar 7. Halaman Registrasi
4) Halaman Input Keluhan

Pertama responden dipastikan telah melakukan registrasi agar dapat melakukan komplain. Responden harus memasukan NIK sesuai dengan data diri maka responden dapat menuangkan keluhan rasa ketidakpuasan terhadap intasni.

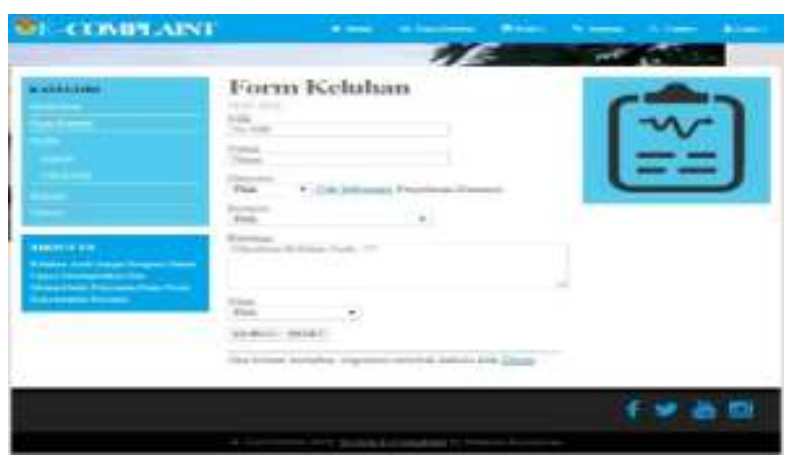

Gambar 8. Halaman Keluhan

5) Halaman Data Dimensi

Halaman input data dimensi adalah halaman yang menampilkan data-data dimensi. Pada halaman ini form input, tombol daftar untuk simpan data, tombol reset. Edit data dimensi digunakan untuk mengubah data dimensi apabila terjadi kesalahan data dan hapus digunakan untuk menghapus data-data dimensi yang telah disimpan.

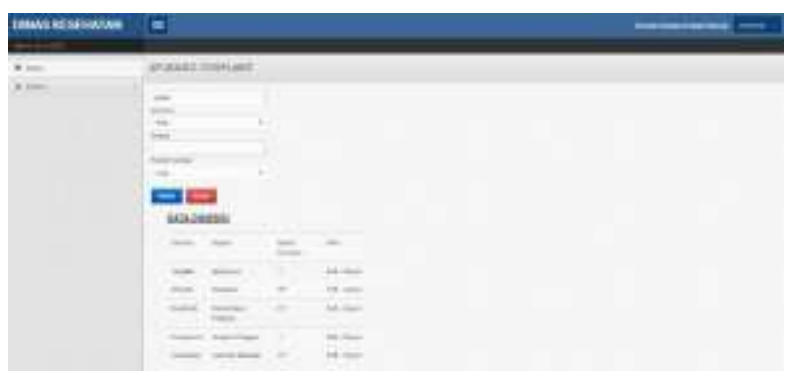

Gambar 9. Halaman Data Dimensi

6) Halaman Data Responden

Halaman data responden ini untuk menampilkan dataresponden yang telah diinput seblumnya.Admin dapat melihat dan mengelola data responden yang telah melakukan registrasi.

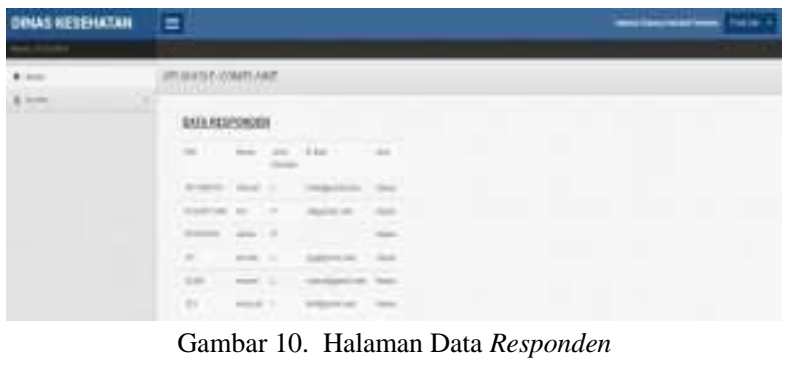

7) Halaman Data user

Jurnal Ilmiah Binary STMIK Bina Nusantara Jaya Vol. 01 No. 01 Tahun 2019, ISSN : 2657-2117 
Halaman input data useradalah halaman yang menampilkan data-data user untuk login. Pada halaman ini form input, tombol daftar untuk simpan data, tombol reset. Edit data user digunakan untuk mengubah data user apabila terjadi kesalahan data dan hapus digunakan untuk menghapus data-data user yang telah disimpan.

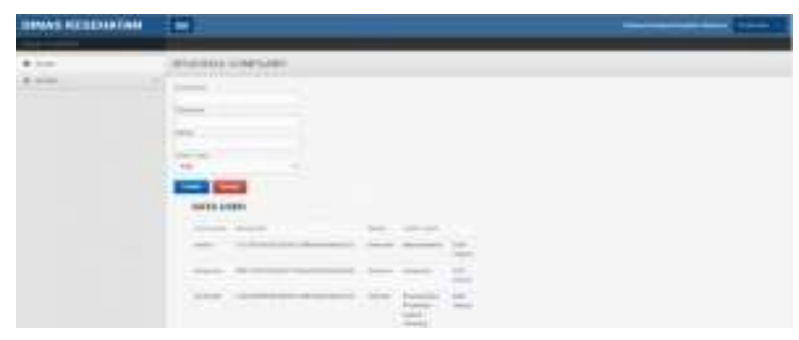

Gambar 11. Halaman Data User

\section{8) Halaman Hasil}

Halaman Hasil merupakan halaman yang menampilkan data hasil dari komplain yang di analisis mengguakan metode servqual. Nilai dari responden dan nilai yang harus di capai intansi di analisis untuk mendapatkan hasil. Proses mengelola data komplain menggunakan metode servqual. Metode ini digunakan untuk menganalisis seluruh nilai komplain yang di berikan oleh responden dan instansi. Dari hasil perhitungan akan di dapatkan nilai rata-rata dari responden maupun intansi. Kemudian akan didapatkan hasil berupa nilai pelayanan mana yang terendah. Jadi pelayanan yang terendah akan dilakukan perbaikan.

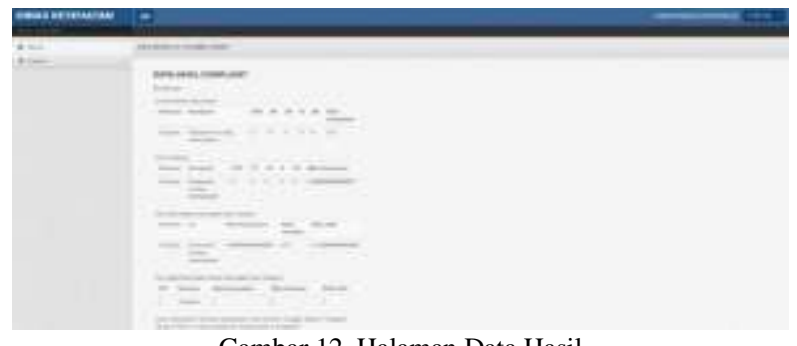

Gambar 12. Halaman Data Hasil

\subsection{Pembahasan Hasil}

Dari hasil sistem berikut pembahasan cara menganalisis perhitungan dengan menggunakan metode servqual dengan menggunakan 50 data responden. Dalam pengukuran pelayanan dalam metode servqual ini didasarkan pada skala multi item yang dirancang untuk mengukur harapan dana kenyataan responden. Serta GAP diantara keduanya pada lima dimensi kualitas layanan yaitu daritangiles (bukti terukur / berwujud), reliability (keandalan), responsiveness (daya tanggap), assurance (jaminan), empathy (empati). Berikut Kelima dimensi dijabarkan dalam beberapa pernyataan untuk atribut kenyataan sebagai berikut :

1. Sangat Tidak Baik $=$ STB $($ bobot 1$)$.

2. Tidak Baik $=$ TB $($ bobot 2$)$.

3. Cukup Baik $=\mathrm{CB}$ (bobot 3 )

4. Baik = B (bobot 4$)$.

5. Sangat Baik $=$ SB (bobot 5 ).

Nilai kenyataan dari 50 responden dihitung berdasarkan item by item analysis dimana symbol $\mathrm{K}=$ Kenyataan :

a. Analisis Nilai Kenyataan Tangible $\mathrm{H}=\left(\sum \mathrm{STB} \times 1\right)+\left(\sum \mathrm{TB} \times 2\right)+\left(\sum \mathrm{CB} \times 3\right)+\left(\sum \mathrm{B} \mathrm{x}\right.$ $4)+\left(\sum \mathrm{SB} \times 5\right)$

$\mathrm{H}=(0 \times 1)+(1 \times 2)+(7 \times 3)+(2 \times 4)+(1 \times 5)$

$\mathrm{H}=0+2+21+8+5$

$\mathrm{H}=36 / 50=0.72$

b. Analisis Nilai Kenyataan Realibity

$\mathrm{H}=\left(\sum \mathrm{STB} \times 1\right)+\left(\sum \mathrm{TB} \times 2\right)+\left(\sum \mathrm{CB} \times 3\right)+\left(\sum \mathrm{B} \times\right.$ $4)+\left(\sum \mathrm{SB} \times 5\right)$

$\mathrm{H}=(0 \times 1)+(5 \times 2)+(4 \times 3)+(1 \times 4)+(0 \times 5)$

$\mathrm{H}=0+10+12+4+0$

$\mathrm{H}=26 / 50=0.52$

c. Analisis Nilai Kenyataan Responsivenss $\mathrm{H}=\left(\sum \mathrm{STB} \times 1\right)+\left(\sum \mathrm{TB} \times 2\right)+\left(\sum \mathrm{CB} \times 3\right)+\left(\sum \mathrm{B} \mathrm{x}\right.$ $4)+\left(\sum \mathrm{SB} \times 5\right)$

$\mathrm{H}=(0 \times 1)+(1 \times 2)+(9 \times 3)+(0 \times 4)+(0 \times 5)$

$\mathrm{H}=0+2+27+0+0$

$\mathrm{H}=29 / 50=0.58$

d. Analisis Nilai Kenyataan Assurance

$\mathrm{H}=\left(\sum \mathrm{STB} \times 1\right)+\left(\sum \mathrm{TB} \times 2\right)+\left(\sum \mathrm{CB} \times 3\right)+\left(\sum \mathrm{B} \times\right.$ 4) $+\left(\sum \mathrm{SB} \times 5\right)$

$\mathrm{H}=(2 \times 1)+(3 \times 2)+(1 \times 3)+(2 \times 4)+(2 \times 5)$

$\mathrm{H}=2+6+3+8+10$

$\mathrm{H}=29 / 50=0.58$

e. Analisis Nilai Harapan Empaty

$\mathrm{H}=\left(\sum \mathrm{STB} \times 1\right)+\left(\sum \mathrm{TB} \times 2\right)+\left(\sum \mathrm{CB} \times 3\right)+\left(\sum \mathrm{B}\right.$ x $4)+\left(\sum \mathrm{SB} \times 5\right)$

$\mathrm{H}=(0 \times 1)+(0 \times 2)+(9 \times 3)+(1 \times 4)+(0 \times 5)$

$\mathrm{H}=0+0+27+4+0$

$\mathrm{H}=31 / 50=0.62$

Tabel 1.Tabel Nilai Kenyataan

\begin{tabular}{|l|c|c|c|c|c|c|}
\hline DIMENSI & STB & TB & CB & B & SB & $\begin{array}{c}\text { NILAI } \\
\text { RATA-RATA } \\
\text { KENYATAA } \\
\text { Tangibel }\end{array}$ \\
\hline Reability & 0 & 1 & 7 & 2 & 0 & 0.62 \\
\hline $\begin{array}{l}\text { Responsive } \\
\text { nss }\end{array}$ & 0 & 1 & 9 & 0 & 0 & 0.58 \\
\hline Assurance & 2 & 3 & 1 & 2 & 2 & 0.58 \\
\hline Empaty & 0 & 0 & 9 & 1 & 0 & 0.62 \\
\hline Jumlah & & & & & 50 & \\
\hline
\end{tabular}

Kelima dimensi kualitas tersebut dijabarkan dalam beberapa pernyataan untuk atribut harapan sebagai berikut :

1. Sangat Tidak Tepat $=$ STB $($ bobot 1$)$. 
2. $\quad$ Tidak Tepat $=$ TT $($ bobot 2$)$.

3. Cukup Tepat $=\mathrm{CT}($ bobot 3$)$

4. Tepat $=\mathrm{T}($ bobot 4$)$.

5. Sangat Tepat $=$ ST $($ bobot 5$)$.

Maka untuk nilai harapan telah ditetapkan dari Dinas Kesehatan Kota Lubuklinggau dengan masingmasing dimensi dengan nilai tangible tidak tepat(2), reability cukup tepat(3),Responsivenss tepat(4), Assurance cukup tepat(3),empaty tidak tepat(2) nilai tersebut digunakan perperiode. Dari 50 responden tiaptiap hasil kenyataan nilai harapan didapatkan dari peresponden yang melakukan komplain sesuai dengan nilai dimensi dimensi yang telah ditetapkan pada periode ini berikut perhitungan berdasarkan item by item analysis dimana symbol $\mathrm{H}=$ Harapan :

a. Analisis Nilai Harapan Tangible

$\mathrm{H}=\left(\sum \mathrm{STT} \times 1\right)+\left(\sum \mathrm{TT} \times 2\right)+\left(\sum \mathrm{CT} \times 3\right)+\left(\sum \mathrm{T}\right.$ x $4)+\left(\sum \mathrm{ST} \times 5\right)$

$\mathrm{H}=(0 \times 1)+(10 \times 2)+(0 \times 3)+(0 \times 4)+(0 \times 5)$

$\mathrm{H}=0+20+0+0+0$

$\mathrm{H}=20 / 50=0.4$

b. Analisis Nilai Harapan Realibity

$\mathrm{H}=\left(\sum \mathrm{STT} \times 1\right)+\left(\sum \mathrm{TT} \times 2\right)+\left(\sum \mathrm{CT} \times 3\right)+\left(\sum \mathrm{T}\right.$ x $4)+\left(\sum \mathrm{ST} \times 5\right)$

$\mathrm{H}=(0 \times 1)+(0 \times 2)+(10 \times 3)+(0 \times 4)+(0 \times 5)$

$\mathrm{H}=0+0+30+0+0$

$\mathrm{H}=30 / 50=0.6$

c. Analisis Nilai Harapan Responsivenss

$\mathrm{H}=\left(\sum \mathrm{STT}\right.$ x 1) $+\left(\sum \mathrm{TT}\right.$ x 2$)+\left(\sum \mathrm{CT}\right.$ x 3$)+\left(\sum \mathrm{T}\right.$ x $4)+\left(\sum \mathrm{ST} \times 5\right)$

$\mathrm{H}=(0 \times 1)+(0 \times 2)+(0 \times 3)+(10 \times 4)+(0 \times 5)$

$\mathrm{H}=0+0+0+40+0$

$\mathrm{H}=40 / 50=0.8$

d. Analisis Nilai Harapan Assurance

$\mathrm{H}=\left(\sum \mathrm{STT} \times 1\right)+\left(\sum \mathrm{TT}\right.$ x 2$)+\left(\sum \mathrm{CT}\right.$ x 3$)+\left(\sum \mathrm{T}\right.$ x $4)+\left(\sum \mathrm{ST} \times 5\right)$

$\mathrm{H}=(0 \times 1)+(0 \times 2)+(10 \times 3)+(0 \times 4)+(0 \times 5)$

$\mathrm{H}=0+0+30+0+0$

$\mathrm{H}=30 / 50=0.6$

e. Analisis Nilai Harapan Empaty

$\mathrm{H}=\left(\sum \mathrm{STT} \times 1\right)+\left(\sum \mathrm{TT} \times 2\right)+\left(\sum \mathrm{CT} \times 3\right)+\left(\sum \mathrm{T}\right.$ x $4)+\left(\sum \mathrm{ST} \times 5\right)$

$\mathrm{H}=(0 \times 1)+(0 \times 2)+(10 \times 3)+(0 \times 4)+(0 \times 5)$

$\mathrm{H}=0+20+0+0+0$

$\mathrm{H}=20 / 50=0.4$

\begin{tabular}{|c|c|c|c|c|c|c|}
\hline \multicolumn{7}{|c|}{ Tabel 2.TabelNilai Harapan } \\
\hline DIMENSI & STT & TT & CT & $\mathbf{T}$ & ST & $\begin{array}{c}\text { NILAI } \\
\text { RATA- } \\
\text { RATA } \\
\text { HARAPA } \\
\text { N }\end{array}$ \\
\hline Tangible & 0 & 10 & 0 & 0 & 0 & 0.4 \\
\hline Realibity & 0 & 0 & 10 & 0 & 0 & 0.6 \\
\hline $\begin{array}{l}\text { Responsins } \\
\text { ivense }\end{array}$ & 0 & 0 & 0 & 10 & 0 & 0.8 \\
\hline Assurance & 0 & 0 & 10 & 0 & 0 & 0.6 \\
\hline Empaty & 0 & 10 & 0 & 0 & 0 & 0.4 \\
\hline Jumlah & & & & & 50 & \\
\hline
\end{tabular}

Seteleh nilai harapan dan kenyataan didapat selanjutnya mencari nilai GAP dari 5 dimensi sebagai berikut dengan symbol $\mathrm{G}=\mathrm{K}-\mathrm{H}$ :
a. Nilai GAP Tangible
$\mathrm{G}=\mathrm{K}-\mathrm{H}$
$\mathrm{G}=0.72-0.4=0.3$

b. Nilai GAP Realibity

$\mathrm{G}=\mathrm{K}-\mathrm{H}$

$\mathrm{G}=0.52-0.6=-0.08$

c. Nilai GAP Responsivness

$\mathrm{G}=\mathrm{K}-\mathrm{H}$

$\mathrm{G}=0.58-0.8=-0.22$

d. Nilai GAP Assurance

$\mathrm{G}=\mathrm{K}-\mathrm{H}$

$\mathrm{G}=0.58-0.6=-0.2$

e. Nilai GAP Empaty

$\mathrm{G}=\mathrm{K}-\mathrm{H}$

$\mathrm{G}=0.62-0.4=0.22$

\begin{tabular}{|l|c|c|c|c|}
\hline \multicolumn{4}{|c|}{ Tabel 3. Tabel Nilai GAP (Hasil) } \\
\hline DIMENSI & $\begin{array}{c}\text { NILAI } \\
\text { KENYATA } \\
\text { AN }\end{array}$ & $\begin{array}{c}\text { NILAI } \\
\text { HARAP } \\
\text { AN }\end{array}$ & $\begin{array}{c}\text { NIL } \\
\text { AI } \\
\text { GAP }\end{array}$ & $\begin{array}{c}\text { KETERAN } \\
\text { GAN }\end{array}$ \\
\hline Tangible & 0.62 & 0.4 & 0.22 & $\begin{array}{c}\text { CUKUP } \\
\text { BAIK }\end{array}$ \\
\hline Realibity & 0.52 & 0.6 & -0.08 & $\begin{array}{c}\text { BELUM } \\
\text { BAIK }\end{array}$ \\
\hline $\begin{array}{l}\text { Responsinsi } \\
\text { ness }\end{array}$ & 0.58 & 0.8 & -0.22 & $\begin{array}{c}\text { BELUM } \\
\text { BAIK }\end{array}$ \\
\hline Assurance & 0.58 & 0.6 & -0.02 & $\begin{array}{c}\text { BELUM } \\
\text { BAIK }\end{array}$ \\
\hline Empaty & 0.62 & 0.4 & 0.22 & $\begin{array}{c}\text { CUKUP } \\
\text { BAIK }\end{array}$ \\
\hline
\end{tabular}

Dari hasil yang didapat jika kualitas nilai di bawah 0 maka pelayanan dikategorikan belum baik dan perlu perbaikan, apabila kualitas nilai 0 sampai 0,5 maka pelayanan dikategorikan cukup baik dan jika nilai 0,6 keatas maka dikategorikan baik, sehigga perlu di pertahanka. Dari hasil pengujian dari 50 data responden hasil di dapat :

1. Tangible $=0.32$

2. Reability $=-0.08$

3. Responsivenss $=-0.22$

4. Assurance $=-0.2$

5. Empaty $=0.22$

Maka dimensi tangible dan empaty dikategorikan baik sedangkan reability, responsivenss, dan assurance dikategorikan belum baik maka harus diproritaskan untuk di perbaiki. 


\section{Kesimpulan}

\subsection{Simpulan}

Berdasarkan dari hasil penelitian, maka penulis dapat mengambil kesimpulan yaitu :

1) Hasil penelitian ini menghasilkan sebuah sistem E-Complaint dalam upaya meningkatkan mutu pelayanan dengan menggunakan metode servqual. Dengan di dalamnya terdapat 5 dimensi terdiri dari tangiles (bukti terukur / berwujud), reliability (keandalan), responsivenss (daya tanggap), assurance (jaminan), empathy (empati).

2) Berdasarkan pengukuran terhadap 5 dimensi kualitas pelayanan dari 50 data responden, didapat hasil bahwa ada 3 atribut kualitas pelayanan yang memiliki nilai terendah yaitu reability, responsinsiness, dan assurance. Artinya dimensi pelayanan inilah yang harus menjadi prioritas untuk dievaluasi dan ditingkatkan lagi kualitas pelayanannya oleh pihak Dinas Kesehatan Kota Lubuklinggau.

\subsection{Saran}

Dari hasil penelitian penulis mengusulkan beberapa saran. Berikut beberapa saran yang penulis berikan yaitu :

1) Pada sistem ini menerapkan metode servqual masih dapat dikembangkan lagi dengan kombinasi metode lainnya.

2) Diharapkan adanya pengembang selanjutnya menjadikan sistem ini berbasis aplikasi android.
Kantor Imigrasi ( Studi Tentang Peningkatan Kualitas Pelayanan Surat Perjalanan Republik Indonesia di Kantor Imigrasi Klas I Khusus Surabaya )," vol. 1, 2013.

[6] B. Widyastuti, "Analisis Kualitas Pelayanan Perizinan Investasi di UPT Pelayanan Perizinan Terpadu ( P2T ) Provinsi dalam Meningkatkan Investasi di Jawa Timur," vol. 1, pp. 1-8, 2014.

[7] M. M. K. Ir. Aliyadi, "EVALUASI KUALITAS LAYANAN SISTEM INFORMASI AKADEMIK DENGAN METODE SERVQUAL (STUDI KASUS DI UNIVERSITAS MUHAMMADIYAH PONOROGO," vol. 4, 2015.

[8] A. S. Rosa and M.Shalahuddin, Rekayasa Perangkat Lunak. 2013.

[9] D. E. Hendrianto, "Pembuatan Sistem Informasi Perpustakaan Berbasis Website Pada Sekolah Menegah Pertama Negeri 1 Donorojo Kabupaten Pacitan," Indones. Juournal Netw. Secur., vol. 3, no. 4, pp. 57-64, 2014.

[10] M. ko. Robi Yanto, Manajemen Basis Data Menggunakan MySQL. Yogyakarta, 2016.

[11] M. Sudarmaji, "Rancang bangun majalah kampus online berbasis web," J. Inf. Politek. Indonusa Surakarta, vol. 1, no. 1, pp. 53-59, 2015.

[12] A. S. H, "PERANCANGAN MAIL SERVER INTRANET BERBASIS WEB BASE DENGAN OPTIMALISASI OPERASI SISTEM CLIENT," no. 1, pp. 1-10, 2015.

\section{Daftar Pustaka}

[1] V. Sahfitri, "MENGGUNAKAN SERVQUAL METHODE," no. 12, pp. 105-114, 2014.

[2] Akhmadsyukron, "Perancangan Sistem Rawat Jalan Berasis web Pada Puskesmas Winog," Informatika, vol. 3, no. 1, pp. 28-34, 2015.

[3] P. Informatika and B. Darma, "Diterbitkan Oleh : STMIK Budi Darma Medan Diterbitkan Oleh : STMIK Budi Darma Medan,” vol. I, pp. 5-10, 2012.

[4] S. Indriyani and S. Mardiana, "Pengaruh Penanganan Keluhan (Complaint Handling) Terhadap Kepercayaan dan Komitmen Mahasiswa Pada Perguruan Tinggi Swasta Di Bandar Lampung," Bisnis Darmajaya, vol. 2, no. 01, p. $13,2016$.

[5] L. Samsara, "Inovasi Pelayanan Paspor di 
Jurnal Ilmiah Binary STMIK Bina Nusantara Jaya Vol. 01 No. 01 Tahun 2019, ISSN : 2657-2117 